\title{
ANALISIS PEMASARAN RUMAH SEDERHANA BAGI MASYARAKAT BERPENGHASILAN RENDAH (STUDI KASUS DI WILAYAH KABUPATEN BEKASI JAWA BARAT)
}

\author{
Edi Firmansyah'; Agustian Zein² Beti Nurbaiti3 \\ Magister Manajemen Fakultas Ekonomi Universitas Bhayangkara Jakarta Raya ${ }^{1,2,3}$ \\ edi.firmansyah@yahoo.com¹; agustian.zein@gmail.com²; bettysigit@gmail.com³
}

\begin{abstract}
ABSTRAK
Tujuan penelitian ini adalah untuk mengetahui dan menganalisa apakah persoalan kualitas rumah, subsidi, insentif pemerintah dan harga Jual berpengaruh terhadap Kepuasan Konsumen dengan Keputusan Membeli sebagai Variabel Interveningnya.. Penelitian ini menggunakan teknik sampling jenuh. Populasi penelitian ini adalah seluruh pegawai Biro Keuangan BNPB yang berjumlah 36 orang. Metode Penelitian ini menggunakan metode penelitian kuantitatif dengan program komputer Structural Equation Modeling (SEM). Dan Linear Structural Relationship (Lisrel). Hasil penelitian menunjukkan terdapat pengaruh yang signifikan Kualitas Produk terhadap Keputusan Membeli. dengan nilai T Statistics 5.09 lebih besar dari t tabel 1.96. Tidak terdapat pengaruh yang signifikan Subsidi/Insentif Pemerintah terhadap Keputusan Membeli dengan nilai $\mathrm{T}$ Statistics 1.6o lebih kecil dari t tabel 1.96. Tidak terdapat pengaruh yang signifikan Harga Jual terhadap Keputusan Membeli. Ketika Pemerintah memberlakukan kebijakan satu harga. dengan nilai T Statistics o.oo lebih kecil dari t tabel 1.96. Terdapat pengaruh yang signifikan Keputusan Membeli terhadap Kepuasan Konsumen dengan nilai T Statistics 3.37 lebih besar dari t tabel 1.96. terdapat pengaruh yang signifikan Kualitas Produk terhadap Kepuasan Konsumen dengan nilai $T$ Statistics -2.30 lebih kecil dari t tabel 1.96. terdapat pengaruh yang signifikan Subsidi/Insentif Pemerintah terhadap Kepuasan Konsumen dengan nilai $\mathrm{T}$ Statistics $\mathbf{- 1 . 7 4}$ lebih kecil dari t tabel 1.96. Terdapat pengaruh yang signifikan Harga Jual terhadap Kepuasan Konsumen dengan nilai T Statistics 3.15 lebih besar dari t tabel 1.96
\end{abstract}

Kata kunci: Rumah Sederhana, Masyarakat berpenghasilan Rendah, Kualitas Produk, Subsisdi atau Insentif Pemerintah, Keputusan membeli, Kepuasan Konsumen dan Structural Equation Modeling, Lisrel 8.8.

SIMPLE HOUSE MARKETING ANALYSIS FOR LOW INCOME COMMUNITIES

(CASE STUDY IN BEKASI REGENCY, WEST JAVA)

ABSTRACT

The purpose of this research is to know and analyze Is the issue of House quality, Government Subsidy / Incentives and Selling Price have an effect on to Consumer 
Satisfaction with Buying Decision as Intervening Variable. This research use saturated sampling technique. The population of this research is Consumers of Purilestari housing residents and Gramapuri Persada housing residents which run 267 families people. This research method uses quantitative research method with computer program Structural Equation Modeling (SEM). And Linear Structural Relesionship (Lisrel). The results showed that there is a significant effect of Product Quality on Buying Decision. with the value of T Statistics 5.09> 1.96. There is no significant effect of Government Subsidy / Incentives on Buying Decision with the value of T Statistics $1.60 \leq 1.96$. There is no significant effect of Selling Price on Buying Decision. When the Government imposes a one price policy. with the value of T Statistics $0.00 \leq 1.96$. There is a significant influence Buying Decision on Consumer Satisfaction with the value of T Statistics 3.37> 1.96.. There is a significant influence on Product Quality on Consumer Satisfaction with the T Statistics value of $-2.30 \leq 1.96$. There is a significant influence of Government Subsidies / Incentives on Consumer Satisfaction with $T$ Statistics -1.74 $\leq 1.96$. There is a significant effect of Price Price on Consumer Satisfaction. with the value of T Statistics 3.15>1.96.

\section{Keywords; Simple House, Low Income People, Product Quality, Subsistence or Government Incentives, Buying Decision, Consumer Satisfaction, Structural Equation Model}

Diterima: 15 Agust 2019; Direvisi: 16 Sept 2019; Diterbitkan: 30 Okt 2019

\section{PENDAHULUAN}

Seharusnya setiap warga negara Indonesia berhak mendapatkan hak bermukim yang Berdasarkan data dari Kementerian Perumahan Rakyat pada tahun 2015-2016, jumlah permintaan rumah di Jakarta mencapai 42.239, 60.000 dan 70.000 unit/tahun rumah baru, perkiraan penawaran rumah baru hanya 20.000, 16.006, dan 40.000 unit/tahun. Dipihak lain perkiraan jumlah permintaan rumah baru di kota Bekasi menurut Badan Perencanaan dan Pembangunan Daerah Kota Bekasi pada tahun 2009-2011 sekitar 16.847, 15.315 dan 30.000 unit/tahun, sedangkan penawaran rumah baru di kota Bekasi hanya 7.515, 4.592 dan 12.000 unit/tahun .Banyaknya rumah-rumah kumuh (slum dan squater) yang berada dipinggiran kabupaten Bekasi, yang mengidentifikasikan adanya ketidakmampuan penduduk untuk membeli rumah yang memadai, yang menandakan bahwa fungsi sosial perumahan tidak berjalan dengan baik. Sebaliknya, banyak rumah-rumah sedang dan mewah yang tetap menjadi fokus pembangunan oleh beberapa pengembang perumahan, yang menunjukkan bahwa fungsi ekonomi dari perumahan tetap menjadi prioritas utama.

Ada beberapa cara komunikasi pemasaran perumahan bagi perusahaaan, antara lain, iklan, hubungan masyarakat dan tenaga penjual, informasi yang disampaikan secara optmal yang dilakukan perusahaan pengembang menjadi factor penting untuk menentukan pemilihan masyarakat dalam membeli rumah. Kemampuan dan atribut atribut promosi yang digunakan perusahaan dalam menarik calon pembeli menentukan keberhasilan sebuah kawasan hunian segera terserap pasar atau terbeli oleh masyarakat.

Menjadi sebuah keniscayaan bahwa peranan developer tidak hanya memasarkan perumahan dan membangun fisik lingkungan tetapi juga berperan didalam Pembangunan sumberdaya manusia dan kelembagaan masyarakat yang saat ini masih belum optimal khususnya menyangkut kesadaran akan pentingnya hidup sehat. 
Jakarta merupakan salah satu kota dengan tingkat kebutuhan rumah yang sangat tinggi. Penduduk kota Jakarta dari tahun ke tahun terus bertambah. Selain karena kelahiran, banyaknya pendatang dari daerah lain membuat Jakarta semakin padat. Berdasarkan data Badan Pusat Statistik, jumlah pertumbuhan penduduk kota Jakarta mencapai rata-rata 8.782.031 jiwa Pertumbuhan jumlah penduduk kota Jakarta dengan Persentase rata-rata per tahun 2,48\%. Hal ini terjadi juga pada Kabupaten Bekasi sebagai kota penyanggah Jakarta, penduduknyapun ikut terus bertambah. Berdasarkan Badan Pusat Statistik, jumlah pertumbuhan penduduk kota Bekasi mencapai rata-rata 2.052.901 jiwa. Pertumbuhan jumlah penduduk Kabupaten Bekasi dengan persentase rata-rata per tahun $11,65 \%$.

Faktor pembiayaan menjadi factor penting bagi sebagian konsumen atau masyarakat, masyakat atau konsumen berpendapat bahwa kemudahan pembiayaan pembelian rumah itu penting dalam pembelian rumah, hal yang mendukung dan terkait dengan pembiayaan adalah besaran uang muka dan cicilan rumah yang terjangkau yang dapat membuat ketertarikan untuk membeli rumah walaupun harga dan lokasi rumah tidak sebaik pilihan lain Untuk mendukung pelaksanaannya, pemerintah telah mengeluarkan berbagai kebijakan berupa subsidi/Insentif Pemerintah sebagai pendukungnya, misalnya dengan menyediakan paket pinjaman kredit dengan subsidi suku bunga sehingga cicilan dan uang muka menjadi ringan pembebasam pajak PPn dan BPHTB berdampak pada harga jual menjadi rendah, standarisasi harga jual dan kualitas bangunan berimplikasi kepada menghindari terjadinya fluktuasi harga jual ditingkat konsumen karena pihak pengembang atau developer dapat menentukan harga jual semaunya mereka dengan berbagai alasan. .

Sementara itu, harga berbagai komponen pembangunan perumahan yang meningkat, seperti harga lahan dan material bangunan, serta semakin berkurangnya daya beli masyarakat menjadikan Harga jual rumah semakin sulit terjangkau oleh sebagian besar masyarakat. Hal ini disebabkan Adanya persepsi bahwa rumah tidak hanya dilihat dalam fungsi sosial, tetapi cenderung pada fungsi ekonomi, serta mengindikasikan adanya ketimpangan didalam pemenuhan antara kebutuhan (demand) yang cenderung bersifat sosial, dan produk yang disediakan (supply) yang cenderung bersifat ekonomis.

Berdasarkan fakta-fakta di atas, peluang pemasaran dan pembangunan perumahan dengan harga jual yang terjangkau bagi Masyarakat Berpeghasilan Rendah (MBR) masih sangat terbuka. Di sisi produsen, produk perumahan yang inovatif diharapkan mampu memenuhi kebutuhan konsumen dan pangsa pasar yang besar. Selain itu, dengan pembangunan dan pengembangan perumahan dengan harga yang terjangkau diharapkan dapat memberikan kontribusi sosial kepada negara khususnya untuk Masyarakat Berpenghasilan Rendah (MBR).

Kabupaten Bekasi dengan penduduk berjumlah lebih dari 1,3 juta jiwa dengan pertumbuhan rata-rata $1,34 \%$ pertahun, ditunjang oleh ketersediaan potensi luas Iahan belum terbangun, bahan baku di sekitar dan potensi tenaga kerja yang ahli trampil untuk mendukung kegiatan investasi, serta kondisi kota yang kondusif yang ditandai dengan kondisi yang relatif aman, merupakan salah satu kota besar di Indonesia yang memiliki potensi di sektor perumahan untuk menarik investasi di bidang perumahan, dan merupakan pasar yang sangat menarik bagi para pengembang perumahan untuk menanamkan investasinya. tidak kurang dari 93 perumahan telah dibangun oleh lebih dari 15 pengembang perumahan sejak tahun 1975 (Laporan REI, 2016). Perbandingan jumlah pengembang dan jumlah perumahan terbangun menunjukkan bahwa banyak pengembang yang menganggap bahwa Kabupaten Bekasi memiliki potensi pasar dan investasi yang baik di sektor perumahan, 
sehingga mereka cenderung menanamkan investasi di lebih dari satu perumahan.

Suatu produk dapat memuaskan konsumen bila dinilai dapat memenuhi atau melebihi keinginan dan harapannya. Kualitas rumah juga merupakan hal yang paling mendasar dari kepuasan konsumen dan kesuksesan dalam bersaing disetiap perumahan dalam memberikan kualitas yang lebih baik akan memberikan dampak langsung terhadap kepuasan konsumen karena kualitas rumah yang baik dan sesuai yang diinginkan atau sesuai harapan konsumen merupakan hal yang seharusnya menjadi perhatian semua perusahaan pengembang, konsumen berharap perusahaan dapat memberikan kualitas rumah yang baik berupa Design rumah sesuai dengan yang dijanjikan, bahan atau spesifikasi bangunan yang digunakan sesuai standar yang telah disepakati namun sayangnya banyak perusahaan pengembang yang tidak menepati hal hal tersebut yang menyangkut kualitas rumah yang dijanjikan.

Terdapat beberapa hal atau faktor atau Atribut-atribut rumah yang menjadi dasar preferensi atau pertimbangan konsumen dalam memutuskan membeli rumah dapat dibagi dalam dua kategori, yaitu: pertama atribut fisik (terlihat), yang meliputi lokasi, dan fasilitas umum dan fasilitas sosial, dan kedua atribut non-fisik (tidak terlihat), yang meliputi fasilitas pembiayaan kredit pemilikan rumah ("KPR"), kredibilitas pengembang, promosi dan legalitas. Faktor-faktor yang dominan tersebut sebagian konsumen membeli rumah lebih disebabkan oleh faktor harga yang kemudian juga terdapat pertimbangan lokasi yang mudah dijangkau dan strategis selain itu bahwa kemudahan pembiayaan pembelian rumah sangat penting bagi konsumen, terkait dengan pembiayaan adalah besaran uang muka dan cicilan rumah yang terjangkau yang dapat membuat ketertarikan untuk membeli rumah walaupun harga dan lokasi rumah tidak sebaik pilihan lain.

Para pengembang perumahan tidak boleh hanya mementingkan perolehan keuntungan saja, tetapi tetap harus mempertimbangkan tingkat kepuasan Konsumen atau masyarakat, tidak terkecuali bagi Masyarakat Berpenghasilan Rendah mereka berhak mendapatkan haknya sebagai konsumen.

Kabupaten Bekasi yang mayoritas penduduknya adalah pendatang, menjadikan peluang bisnis properti ini tentunya menjadi incaran bagi para pelaku bisnis properti. Sehingga tak heran jika banyak terlihat disetiap daerah di Kabupaten Bekasi menjamur proyekproyek perumahan. Tipe rumah yang dipasarkan beraneka ragam termasuk type rumah sederhana. Tumbuhnya perusahaanperusahaan properti di bidang perumahan menunjukkan potensi pemasaran dan jasa di bidang perumahan di Kabupaten Bekasi yang baik dan menarik.

Pemasaran rumah sederhana di Indonesia masih banyak menghadapi kendala dan persoalan dilapangan, bukan hanya menyangkut jumlah dan banyaknya rumah sederhana yang telah di pasarkan dan diserap ataupun diterima oleh masyarakat tetapi juga menyangkut kualitas rumah serta Harga dan subsidi yang di keluarkan pemenutah hingga sampai ketangan masyarakat.

Pemasaran Rumah sederhana tidaklah sama dengan pemasaran rumah secara umum ataupun seperti yang terjadi pada rumah mewah atau rumah sebagai tempat hunian lainya. dengan beberapa alasan sebagai berikut, 1)Pemasaran rumah sederhana merupakan program Pemerintah yang diberikan hanya bagi masyarakat yang tidak mampu.2) Rumah sederhana hanya diperuntukan bagi masyarakat berpenghasilan rendah.dengan tingkat penghasilan perbulan yang telah ditetapkan ,3)Rumah sederhana hanya dapat dibeli bagi masyarakat yang belum mempunyai rumah atau sebagai rumah pertama dan tidak diperuntukan untuk investasi. 4) Harga ditentukan pemerintah dengan mempertimbangkan tingkat penghasilan minimum masyarakat,.5) Adanya subsidi sedangkan dipemasaran rumah lainnya subsidi ini tidak ada. 
Dengan melihat phenomena tersebutlah maka penelitian ini memfokuskan hanya pada pengaruh Kualitas produk Subsidi/Insentif Pemerntah dan harga Jual terhadap Kepuasan masyarakat sebagai konsumen Rumah Sederhana dengan Keputusan membeli sebagai Variabel Intervenning. Pada umumnya dalam keputusan membeli dan kepuasan konsumen property dan perumahan disamping faktor kualitas ,faktor lokasi dan fasilitas pendukung selalu menjadi faktor utama.

Rumah rumah yang dibangun oleh pihak pengembang selalu dikeluhkan oleh masyarakat baik menyangkut kulitas perumahan yang dibangun juga terhadap pelayanan yang berikan . Hal ini mungkin disebabkan karena pembeli /konsumen rumah sederhana adalah masyarakat kecil yang sangat membutuhkan tempat tinggal sehingga sebagian pengembang berpikir bahwa kualitas dan pelayanan bukanlah hal penting bagi mereka, karena sudah dapat memiliki rumah saja sudah cukup bagi mereka..

Berdasarkan hal tersebut, penulis berharap dapat menganalisa dan mengetahui Bagaimanakah system Pemasaran rumah sederhana untuk masyarakat yang berpenghasilan rendah yang saat ini di sebut dengan rumah bersubsidi. Apakah persoalan tersebut disebabkan oleh Kualitas Rumah (ketepatan ukuran luas tanah dan bangunan, Mutu bahan yang digunakan dan kesesuaian bahan/spesifikasi serta kualitas pengerjaannya,sarana prasaran pendukung dan legalitasnya), Insentif Yang diberikan oleh Pemerintah (Suku bunga kredit, Bantuan uang muka) serta Harga Jual yang diterapkan saat ini memberikan pengaruh terhadap Kepuasan Masyarakat sehingga masyarakat mau dan memutuskan untuk memilih rumah Murah Bersubsidi sebagai tempat tinggal.

\section{KAJIAN TEORETIK}

\section{Pemasaran}

Menurut Philip Kotler dan Amstrong (2001) pemasaran adalah sebagai suatu proses sosial dan managerial yang membuat individu dan kelompok memperoleh apa yang mereka butuhkan dan inginkan lewat penciptaan dan pertukaran timbal balik produk dan nilai dengan orang lain. Philip Kotler (2002) pemasaran adalah kegiatan manusia yang diarahkan untuk memenuhi kebutuhan dan keinginan melalui proses pertukaran.

Pemasaran adalah suatu sistem total dari kegiatan bisnis yang dirancang untuk merencanakan, menentukan harga, promosi dan mendistribusikan barang-barang yang dapat memuaskan keinginan dan mencapai pasar sasaran serta tujuan perusahaan.

Menurut W Stanton (1998) pemasaran adalah sistem keseluruhan dari kegiatan usaha yang ditujukan untuk merencanakan, menentukan harga, mempromosikan dan mendistribusikan barang dan jasa yang dapat memuaskan kebutuhan pembeli maupun pembeli potensial.

Menurut UU No. 4 Tahun 1992 tentang Perumahan dan Permukiman, rumah adalah bangunan yang berfungsi sebagai tempat tinggal atau hunian dan sarana pembinaan keluarga. Menurut John F.C Turner, 1972, dalam bukunya Freedom To Build mengatakan, "Rumah adalah bagian yang utuh dari permukiman, dan bukan hasil fisik sekali jadi semata, melainkan merupakan suatu proses yang terus berkembang dan terkait dengan mobilitas sosial ekonomi penghuninya dalam suatu kurun waktu. Yang terpenting dari rumah adalah dampak terhadap penghuni, bukan wujud atau standar fisiknya.

\section{Rumah}

Menurut UU No. 4 Tahun 1992 tentang Perumahan dan Permukiman, rumah adalah bangunan yang berfungsi sebagai tempat tinggal atau hunian dan sarana pembinaan keluarga. Menurut John F.C Turner, 1972, dalam bukunya 
Freedom To Build mengatakan, "Rumah adalah bagian yang utuh dari permukiman, dan bukan hasil fisik sekali jadi semata, melainkan merupakan suatu proses yang terus berkembang dan terkait dengan mobilitas sosial ekonomi penghuninya dalam suatu kurun waktu. Yang terpenting dari rumah adalah dampak terhadap penghuni, bukan wujud atau standar fisiknya.

\section{Perumahan}

Menurut UU No. 4 Tahun 1992 tentang Perumahan dan Permukiman, perumahan berada dan merupakan bagian dari permukiman, perumahan adalah kelompok rumah yang berfungsi sebagai lingkungan tempat tinggal atau lingkungan hunian yang dilengkapi dengan prasarana dan sarana lingkungan (pasal 1 ayat 2).

Pembangunan perumahan diyakini juga mampu mendorong lebih dari seratus macam kegiatan industri yang berkaitan dengan bidang perumahan dan permukiman (Sumber: Kebijakan dan Strategi Nasional Perumahan dan Permukiman Departemen Permukiman dan Prasarana Permukiman )

\section{Pemukiman}

Menurut Undang-Undang No 4 Tahun 1992 Pasal 3, Permukiman adalah bagian dari lingkungan hidup diluar kawasan lindung, baik yang berupa kawasan perkotaan maupun pedesaan yang berfungsi sebagai lingkungan tempat tinggal atau lingkungan hunian dan tempat kegiatan yang mendukung perikehidupan dan penghidupan. Satuan lingkungan permukiman adalah kawasan perumahan dalam berbagai bentuk dan ukuran dengan penataan tanah dan ruang, prasarana dan sarana lingkungan yang terstruktur (pasal 1 ayat 3). Pasal 4 Undang-Undang Nomor 4 Tahun 1992 menyebutkan bahwa penataan perumahan dan permukiman berlandaskan asas manfaat, adil dan merata, kebersamaan dan kekeluargaan, kepercayaan pada diri sendiri, keterjangkauan, dan kelestarian lingkungan hidup.

\section{Rumah sebagai Produk}

Rumah adalah bangunan yang berfungsi sebagai tempat tinggal atau hunian dan sarana pembinaan keluarga, sebagai kebutuhan dasar manusia. Selain berfungsi sebagai tempat tinggal atau hunian dapat dilihat juga rumah sebagai produk yang dihasilkan dari sebuah proses indusrtiralisasi dari produsen, dalam hal ini kita menyebutnya sebagai Perusahaan Pengembang perumahan,. Maka jika rumah dapat disebut sebagai produk. Menurut Tjiptono (2015) mengemukakan secara konseptual, produk adalah pemahaman subyektif produsen atas "sesuatu" yang dapat ditawarkan sebagai usaha untuk mencapai tujuan organisasi melalui pemenuhan kebutuhan dan keinginan konsumen, sesuai dengan kompetensi dan kapasitas organisasi serta daya beli pasar. Selain itu produk dapat pula didefinisikan sebagai persepsi konsumen yang diajabarkan oleh produsen melalui hasil produksi atau operasinya.

Produk adalah elemen kunci dalam keseluruhan penawaran pasar. Perencanaan bauran pemasaran dimulai dengan merumuskan penawaran yang memberikan nilai bagi pelanggan sasaran. Penawaran ini menjadi dasar bagi perusahaan dalam membangun hubungan yang menguntungkan dengan pelanggan (Kotler dan Amstrong, 2006 ).Kotler dan Amstrong (2006) juga mendefinisikan produk sebagai berikut, produk sebagai segala sesuatu yang dapat ditawarkan kepada pasar agar menarik perhatian, akuisisi, penggunaan, atau konsumsi yang dapat memuaskan suatu keinginan atau kebutuhan. Produk mencakup lebih dari sekadar barangbarang yang berwujud (tangible). Dalam arti luas, produk meliputi objek-objek fisik, jasa, acara, orang, tempat, organisasi, ide, atau bauran entitas-entitas ini.

\section{Kualitas Produk}

Menurut Kotler dan Amstrong (2006) kualitas produk (quality product) adalah salah satu sarana positioning utama pemasar. Kualitas mempunyai dampak langsung pada kinerja produk atau jasa, oleh karena itu 
kualitas berhubungan erat dengan nilai dan kepuasan pelanggan. Dalam arti yang lebih sempit kualitas bisa didefinisikan sebagai "bebas dari kerusakan". Tetapi sebagian besar perusahaan yang berpusat pada pelanggan melangkah jauh melampaui definisi sempit ini. Justru mereka mendefinisikan kualitas berdasarkan penciptaan nilai dan kepuasan pelanggan.

W Edwards Deming (Sumayang, 2003) menjelaskan bahwa kualitas merupakan perbaikan secara berkesinambungan pada sebuah sistem yang stabil. Definisi ini menjelaskan dua hal, yaitu: Semua sistem administrasi, perencanaan, produksi dan sistem penjualan harus stabil yang dibuktikan dengan data-data statistik. Kestabilan ini dapat dilihat dari angka variance yang tetap dan terjadi pada angka rata-rata yang juga tetap. Perbaikan secara berkesinambungan untuk mengurangi penyimpangan dan mendapatkan yang lebih baik untuk pemuasan pelanggan.

\section{Rumah Sederhana}

Yang dimaksud dengan Rumah Murah Bersubsidi atau yang dikenal juga dengan rumah sederhana menurut Kepmenpraswil no 403/KPTS/M/2002 Tentang Pedoman Teknis Pembangunan Rumah Sederhana Sehat (rs sehat) adalah Kebutuhan Minimal Masa (penampilan) dan Ruang (luar-dalam) Kebutuhan ruang per orang dihitung berdasarkan aktivitas dasar manusia di dalam rumah. Aktivitas seseorang tersebut meliputi aktivitas tidur, makan, kerja, duduk, mandi, kakus, cuci dan masak serta ruang gerak lainnya. Dari hasil kajian, kebutuhan ruang per orang adalah $9 \mathrm{~m}^{2}$ dengan perhitungan ketinggian rata-rata langit-langit adalah $2.80 \mathrm{~m}$. Kebutuhan Kesehatan dan Kenyamanan Rumah sebagai tempat tinggal yang memenuhi syarat kesehatan dan kenyamanan dipengaruhi oleh 3 (tiga) aspek, yaitu pencahayaan, penghawaan, serta suhu udara dan kelembaban dalam ruangan.

\section{Subsidi atau Insentif Pemerintah}

Keberhasilan pembangunan perumahan dalam suatu wilayah, baik di perkotaan maupun di pedesaan, tidak terlepas dari peran pemerintah sebagai pihak yang berkewajiban untuk mengarahkan, membimbing, serta menciptakan suasana yang kondusif bagi terciptanya keberhasilan program penyediaan rumah tersebut.

Dalam hal ini pemerintah dapat memberikan subsidi dalam bentuk uang sebagai tambahan penghasilan kepada konsumen/dapat pula pemerintah memberikan subsidi dalam bentuk penurunan harga barang. Artinya dalam mengkonsumsi suatu barang konsumen hanya diwajibkan untuk membayar kurang dari harga barang yang sebenarnya dan selisihnya akan ditanggung oleh pemerintah agar jangan sampai merugikan si produsen barang tersebut. (Suparmoko, 1992). Kebijakan subsidi diberlakukan ketika harga produk suatu rumah dinilai tidak seimbang/sebanding dengan masyarakat berpenghasilan rendah.

\section{Harga Jual.}

Pertimbangan ekonomi dan Keterjangkauan Daya Beli merupakan factor penting yang menjadi perhatian Pemerintah. Tingkat harga merupakan suatu nilai untuk mendapatkan suatu produk, manfaat dari memiliki atau menggunakan pada suatu waktu tertentu. Pada dasarnya tingkat harga yang terjadi dipengaruhi oleh beberapa faktor.

Menurut Swastha (2000), faktor faktor yang mempengaruhi tingkat harga antara lain: keadaan Pemerintah Kondisi Pemerintah sangat mempengaruhi tingkat harga yang berlaku. Pada saat resesi, daya beli konsumen menurun seiring dengan menurunnya nilai tukar uang. Masyarakat menjadi penuh pertimbangan dan selektif dalam memilih produk untuk dikonsumsi. Penawaran dan Permintaan Kuantitas suatu produk akan dibeli tergantung pada tingkat harganya. Semakin 
tinggi harga, semakin sedikit barang atau jasa yang diminta konsumen, sebaliknya semakin rendah tingkat harga, semakin banyak barang atau jasa yang akan konsumen minta. Sedangakan penawaran adalah jumlah produk yang akan ditawarkan ke pasar oleh para pemasok dengan harga yang bervariasi dalam suatu periode tertentu. Elastisitas Permintaan Elastisitas Permintaan mempengaruhi keputusan manajemen untuk menaikkan atau menurunkan harga jual produk. Persaingan yang ketat antara perusahaan sejenis dapat mempengaruhi tingkat harga suatu produk. Biaya merupakan dasar dalam penentuan tingkat harga, tujuan Perusahaan Penetapan harga suatu barang sering dikaitkan dengan tujuan yang akan dicapai.

\section{Keputusan Pembelian}

Perilaku konsumen dipengaruhi oleh beberapa faktor, yakni : 1) kebudayaan, 2) sosial (kelompok referensi, keluarga, peran dan status), 3) kepribadian (usia, jabatan, keadaan/kemampuan ekonomi, gaya hidup, konsumen diri dan kepribadian), dan 4) psikologis (motivasi, kepercayaan dan sikap) (Kotler, 1995). Perilaku konsumen ini dapat pula dipengaruhi faktor internal dan eksternal. Menurut Assael (1987), menyatakan keputusan pembeli sebagai salah satu unit perilaku konsumen dipengaruhi oleh faktor eksternal dan internal. Faktor eksternal terdiri dari budaya, kelompok yang saling berhadapan dengan situasional, sedangkan faktor internal terdiri dari variabel yang ada dalam diri konsumen, seperti kebutuhan, sikap, persepsi, kepribadian, gaya hidup dan karakteristik. Kotler (1995), mengatakan bahwa sikap merupakan faktor internal yang cukup kuat pengaruhnya terhadap perilaku seseorang. Rumah sebagai salah satu kebutuhan utama seseorang, dalam proses pembelian melibatkan konsumen secara pribadi dan seluruh keluarga. Di mana sikap menjalankan evaluasi kognitif, emosional dan ada kecenderungan untuk bertindak menguntungkan atau tidak menguntungkan terhadap suatu obyek atau gagasan.

\section{Kepuasan konsumen.}

Produsen semakin yakin bahwa kunci sukses untuk memenangkan persaingan terletak pada kemampuannya memberikan total costumer value yang dapat memuaskan pelanggan melalui penyampaian rumah yang berkualitas dengan harga bersaing. Pandangan terhadap kepuasan pelanggan sangat bervariasi, keragaman itu akan memberikan pemahaman yang lebih luas (Hasan, 2008), diantaranya: Wilton (1988) menjelaskan bahwa kepuasan/ketidakpuasan pelanggan sebagai respon pelanggan terhadap evaluasi ketidaksesuaian yang dipersepsikan antara harapan sebelum pembelian dan kinerja actual rumah yang dirasakan setelah pemakaiannya. Oliver (1980) merumuskan kepuasan pelanggan sebagai evaluasi purnabeli, dimana persepsi terhadap kinerja Produk yang dipilih memenuhi atau melebihi harapan sebelum pembelian. Apabila persepsi terhadap kinerja tidak dapat memenuhi harapan maka yang terjadi adalah ketidakpuasan. Ketidaksesuaian menciptakan ketidakpuasan.

\section{Kerangka Berpikir dan Hipotesis}

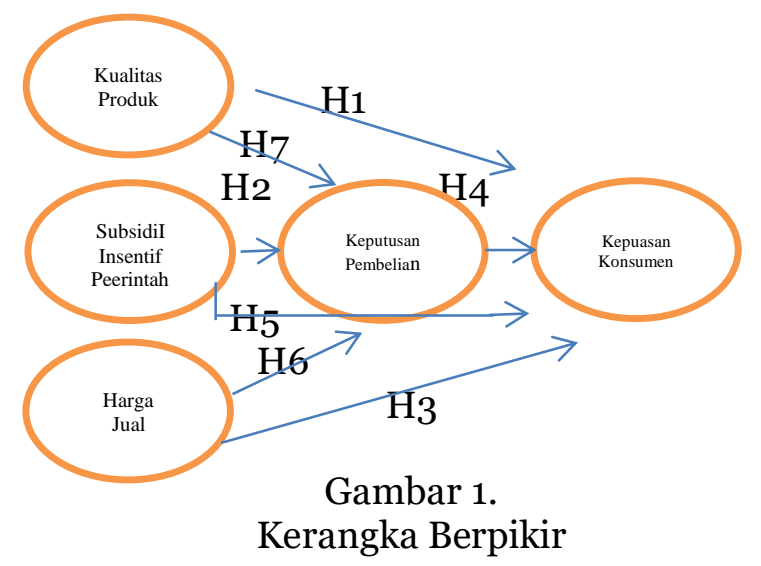

\section{Metode Penelitian}

Metode penelitian dalam penelitian ini adalah metode penelitian kuantitatif dengan analisis uji t, F dan multiple linear regression. Teknik pengumpulan data yang digunakan dalam penelitian ini adalah dengan metode survei. Pengumpulan data dilakukan dengan menggunakan kuesioner. Teknik sampling dalam penelitian ini menggunakan teknik 
random sampling. Populasi dan sample yang digunakan dalam penelitian ini adalah sebanyak 300 kemudian di beri kuesioner yang kembalikan sebanyak 267, namun yang dapat digunakanl dalam penelitian ini hanya sebanyak 225 sampling.

\section{HASIL PENELITIAN DAN PEMBAHASAN}

\section{Hasil Uji Model Pengukuran Variabel Laten KP (Kualitas Produk)}

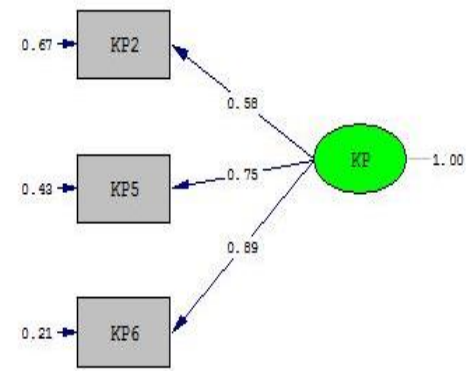

Gambar 2.

Hasil Uji Model Pengukuran Untuk Variabel Laten $K P$

Hasil uji kecocokan model variabel laten KP dapat dilihat dari Goodness Of Fit Index (GOFI) di bawah ini yang sangat baik yaitu "Perfect Fit".

Berdasarkan hasil perhitungan reliabilitas variabel laten KP, maka dapat disimpulkan memiliki validitas dan reliabilitas baik, dengan kecocokan model sempurna.

\section{Hasil Uji Model Pengukuran Variabel Laten SUB (Subsidi / Insentif Pemerintah)}

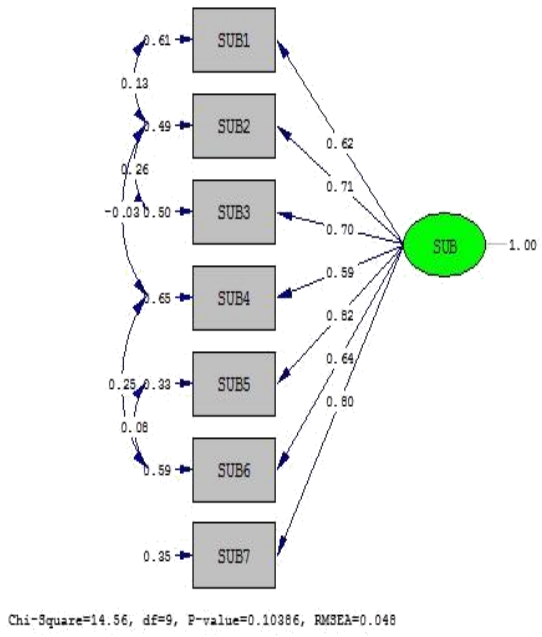

Gambar 3 .

Hasil uji model pengukuran variabel laten Subsidi Insentif Pemerintah (SUB)

Tabel 2.

GOFI Variabel Laten $S U B$

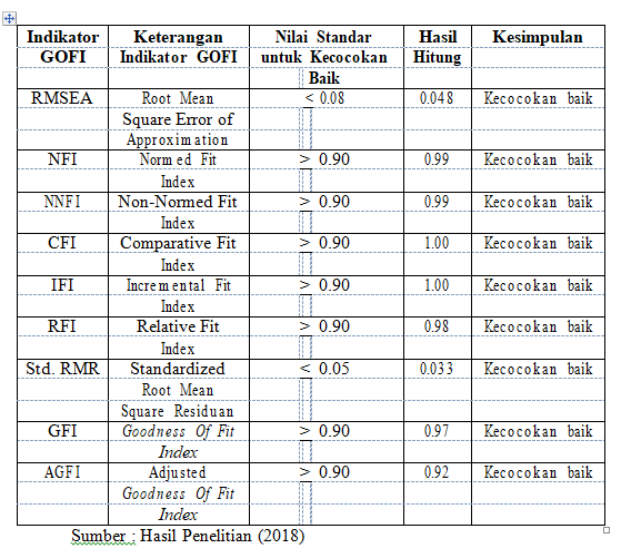

Berdasarkan hasil perhitungan reliabilitas variabel laten SUB, maka dapat disimpulkan memiliki validitas dan reliabilitas baik, dengan kecocokan model baik.

\section{Hasil Uji Model Pengukuran Variabel Laten HJ (Harga Jual)}




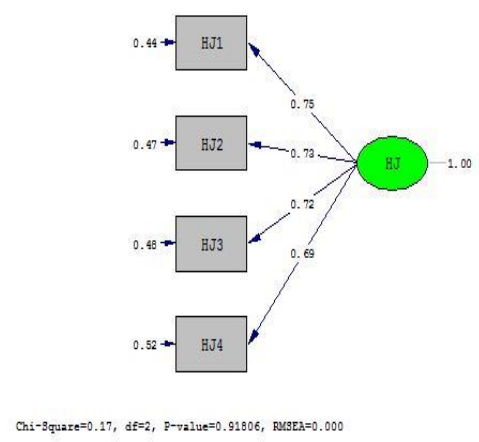

Gambar 4.

Hasil uji model pengukuran variabel laten HJ

Tabel 4.

GOFI Variabel Laten $H J$

\begin{tabular}{|c|c|c|c|c|}
\hline Indikator & Keterangan & Nilai Standar & Hasil & Kesimpulan \\
\hline \multirow{2}{*}{ GOFI } & Indikat or GOFI & untuk Kecocokan & Hitung & \\
\hline & & Baik & & \\
\hline \multirow[t]{3}{*}{ RMSEA } & Root Mean & $<0.08$ & 0.00 & Kecocokan \\
\hline & Square Error of & & & baik \\
\hline & Approximation & & & \\
\hline \multirow[t]{2}{*}{ NFI } & Normed Fit & 0.90 & 1.00 & Kecocokan \\
\hline & Index & & & baik \\
\hline \multirow[t]{2}{*}{ NNFI } & Non-Normed Fit & $\geq 0.90$ & 1.01 & Kecocokan \\
\hline & Index & & & baik \\
\hline \multirow[t]{2}{*}{ CFI } & Comparative Fit & $\geq 0.90$ & 1.00 & Kecocokan \\
\hline & Index & & & baik \\
\hline \multirow[t]{2}{*}{ IFI } & Incremental Fit & 0.90 & 1.00 & Kecocokan \\
\hline & Index & & & baik \\
\hline \multirow[t]{2}{*}{ RFI } & Relative Fit & 0.90 & 1.00 & Kecocokan \\
\hline & Index & & & baik \\
\hline \multirow[t]{3}{*}{ Std. RMR } & Standardized & $<0.05$ & 0.0042 & Kecocokan \\
\hline & Root Mean & & & baik \\
\hline & Square Residuan & & & \\
\hline \multirow[t]{2}{*}{ GFI } & Goodness Of Fit & 0.90 & 1.00 & Kecocokan \\
\hline & Index & & & baik \\
\hline \multirow[t]{3}{*}{ AGFI } & Adjusted & $\geq 0.90$ & 1.00 & Kecocokan \\
\hline & Goodness Of Fit & & & baik \\
\hline & Index & & & \\
\hline
\end{tabular}

Berdasarkan hasil perhitungan reliabilitas variabel laten $\mathrm{HJ}$, maka dapat disimpulkan memiliki validitas dan reliabilitas baik, dengan kecocokan model baik.

\section{Hasil Uji Model Pengukuran Variabel Laten KM (Keputusan Membeli)}

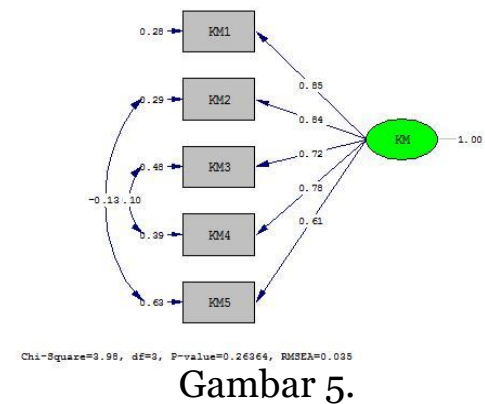

Hasil uji pengukuran variabel laten KM
Tabel 6

GOFI Variabel Laten KM

\begin{tabular}{|c|c|c|c|c|}
\hline \multirow{3}{*}{$\begin{array}{c}\text { Indikator } \\
\text { GOFI }\end{array}$} & Keterangan & Nilai Standar & \multirow{3}{*}{$\begin{array}{l}\text { Hasil } \\
\text { Hitung }\end{array}$} & \multirow[t]{3}{*}{ Kesimpulan } \\
\hline & Indikator GOFI & untuk Kecocokan & & \\
\hline & & Baik & & \\
\hline \multirow[t]{3}{*}{ RMSEA } & Root Mean & $<0.08$ & 0.035 & Kecocokan \\
\hline & Square Error of & & & baik \\
\hline & Approxim ation & & & \\
\hline \multirow[t]{2}{*}{ NFI } & Norm ed Fit & $>0.90$ & 1.00 & Kecocokan \\
\hline & Index & & & baik \\
\hline \multirow[t]{2}{*}{ NNFI } & Non-Normed Fit & $>0.90$ & 1.00 & Kecocokan \\
\hline & Index & & & baik \\
\hline \multirow[t]{2}{*}{ CFI } & Comparative Fit & $>0.90$ & 1.00 & Kecocokan \\
\hline & Index & & & baik \\
\hline \multirow[t]{2}{*}{ IFI } & Incremental Fit & $\geq 0.90$ & 1.00 & Kecocokan \\
\hline & Index & & & baik \\
\hline \multirow[t]{2}{*}{ RFI } & Relative Fit & $>0.90$ & 0.99 & Kecocokan \\
\hline & Index & & & baik \\
\hline \multirow[t]{3}{*}{ Std. RMR } & Standardized & $<0.05$ & 0.016 & Kecocokan \\
\hline & Root Mean & & & baik \\
\hline & Square Residuan & & & \\
\hline \multirow[t]{2}{*}{ GFI } & Goodness Of Fit & 0.90 & 0.99 & Kecocokan \\
\hline & Index & & & baik \\
\hline \multirow[t]{3}{*}{ AGFI } & Adjusted & $>0.90$ & 0.95 & Kecocokan \\
\hline & Goodness of Fit & & & baik \\
\hline & Index & & & \\
\hline Sumber: & sil Penelitian (201 & & & \\
\hline
\end{tabular}

Berdasarkan hasil perhitungan reliabilitas variabel laten $\mathrm{KM}$, maka dapat disimpulkan memiliki validitas dan reliabilitas baik, dengan kecocokan model baik.

\section{Hasil Uji Model Pengukuran Variabel Laten KK (Kepuasan Konsumen)}

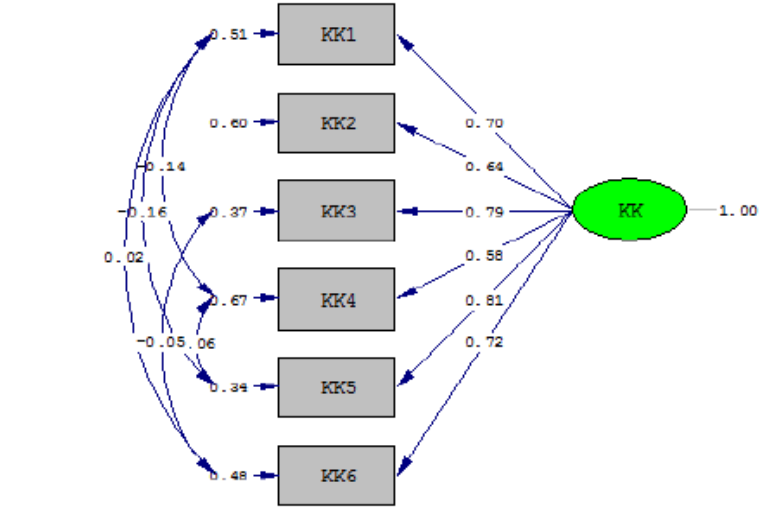

Chi-3quare $=3.64, d f=4, P-v a l u e=0.45733$, RMSEA $=0.000$

Gambar 6.

Hasil uji pengukuran variabel laten $\mathrm{KK}$ 
Tabel 8

GOFI

\begin{tabular}{|c|c|c|c|c|}
\hline $\begin{array}{c}\text { Indikator } \\
\text { GOFI }\end{array}$ & $\begin{array}{c}\text { Keterangan } \\
\text { Indikator GOFI }\end{array}$ & $\begin{array}{c}\text { Nilai Standar } \\
\text { untuk } \\
\text { Kecocokan Baik }\end{array}$ & $\begin{array}{c}\text { Hasil } \\
\text { Hitung }\end{array}$ & Kesimpulan \\
\hline RMSEA & $\begin{array}{c}\text { Root Mean } \\
\text { Square Enror of } \\
\text { Approximation }\end{array}$ & $\leq 0.08$ & 0.00 & Kecocokan baik \\
\hline NFI & $\begin{array}{c}\text { Normed Fit } \\
\text { Index }\end{array}$ & $\geq 0.90$ & 1.00 & Kecocokan baik \\
\hline NNFI & $\begin{array}{c}\text { Non-Normed Fit } \\
\text { Index }\end{array}$ & $\geq 0.90$ & 1.00 & Kecocokan baik \\
\hline CFI & $\begin{array}{c}\text { Comparative Fit } \\
\text { Index }\end{array}$ & $\geq 0.90$ & 1.00 & Kecocokan baik \\
\hline IFI & $\begin{array}{c}\text { Incremental Fit } \\
\text { Index }\end{array}$ & $\geq 0.90$ & 1.00 & Kecocokan baik \\
\hline RFI & $\begin{array}{c}\text { Relative Fit } \\
\text { Index }\end{array}$ & $\geq 0.90$ & 0.99 & Kecocokan baik \\
\hline Std. RMR & $\begin{array}{c}\text { Standardized } \\
\text { Root Mean } \\
\text { Square Residuan }\end{array}$ & $\leq 0.05$ & 0.016 & Kecocokan baik \\
\hline GFI & $\begin{array}{c}\text { Goodness Of Fit } \\
\text { Index }\end{array}$ & $\geq 0.90$ & 0.99 & Kecocokan baik \\
\hline AGFI & $\begin{array}{c}\text { Adjusted } \\
\text { Goodness Of Fit } \\
\text { Index }\end{array}$ & $\geq 0.90$ & 0.97 & Kecocokan baik \\
\hline Sumber : Hasil Penelitian (2018) & \multicolumn{2}{l}{} \\
\hline
\end{tabular}

Berdasarkan hasil perhitungan reliabilitas variabel laten $\mathrm{KK}$, maka dapat disimpulkan memiliki validitas dan reliabilitas baik, dengan kecocokan model baik.

\section{Uji Model Pengukuran Variabel Laten HJL}

Setelah uji model pengukuran dan penyederhanaan variabel laten dilakukan terhadap seluruh variabel laten penelitian, maka tahap selanjutnya adalah melakukan $U j i$ Confirmatory Factor Analysis (CFA) yang bertujuan untuk mengkonfirmasi kembali variabel laten mana saja yang dapat diolah lebih lanjut secara simultan/bersamaan ke tahap uji model struktural penelitian.

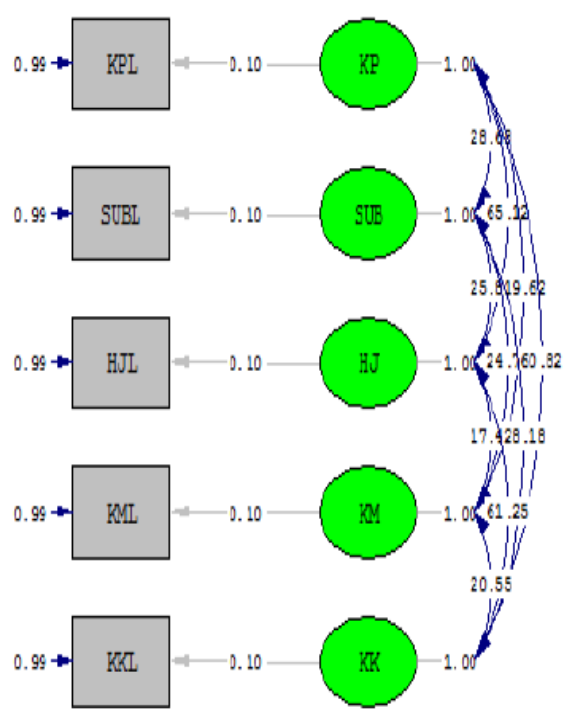

Chi-8quare $=0.00, d f=0$, p-value $=1.00000$, FMERA $=0.000$

Gambar 7.

Uji Confirmatory Factor Analysis /CFA (Standardized Solution)

Hasil uji model pengukuran variabel laten pada uji CFA, terlihat memiliki nilai Standardized Loading Factor (SLF) > 0.50 (validitas baik). Nilai reliabilitasnya baik, dimana nilai CR > 0.70 dan VE > 0.50. Adapun rangkuman hasil validitas dan reliabilitas variabel laten pada uji CFA. 
Tabel 10.

GOFI Variabel Laten Uji Confirmatory Factor Analysis (CFA)

\begin{tabular}{|c|c|c|c|c|}
\hline $\begin{array}{c}\text { Indikator } \\
\text { GOFI }\end{array}$ & $\begin{array}{c}\text { Keterangan } \\
\text { Indikator GOFI }\end{array}$ & $\begin{array}{c}\text { Nilai Standar } \\
\text { untuk Kecocokan } \\
\text { Baik }\end{array}$ & $\begin{array}{c}\text { Hasil } \\
\text { Hitung }\end{array}$ & Kesimpulan \\
\hline RMSEA & $\begin{array}{c}\text { Root Mean } \\
\text { Square Enor of } \\
\text { Approximation }\end{array}$ & $\leq 0.08$ & 0.00 & $\begin{array}{c}\text { Kecocokan } \\
\text { baik }\end{array}$ \\
\hline NFI & $\begin{array}{c}\text { Normed Fit } \\
\text { Index }\end{array}$ & $\geq 0.90$ & 1.00 & $\begin{array}{c}\text { Kecocokan } \\
\text { baik }\end{array}$ \\
\hline NNFI & $\begin{array}{c}\text { Non-Normed Fit } \\
\text { Index }\end{array}$ & $\geq 0.90$ & 1.00 & $\begin{array}{c}\text { Kecocokan } \\
\text { baik }\end{array}$ \\
\hline CFI & $\begin{array}{c}\text { Comparative Fit } \\
\text { Index }\end{array}$ & $\geq 0.90$ & 1.00 & $\begin{array}{c}\text { Kecocokan } \\
\text { baik }\end{array}$ \\
\hline IFI & $\begin{array}{c}\text { Incremental Fit } \\
\text { Index }\end{array}$ & $\geq 0.90$ & 1.00 & $\begin{array}{c}\text { Kecocokan } \\
\text { baik }\end{array}$ \\
\hline RFI & $\begin{array}{c}\text { Relative Fit } \\
\text { Index }\end{array}$ & $\geq 0.90$ & 0.99 & $\begin{array}{c}\text { Kecocokan } \\
\text { baik }\end{array}$ \\
\hline Std. RMR & $\begin{array}{c}\text { Standardized } \\
\text { Root Mean } \\
\text { Square Residuan }\end{array}$ & $\leq 0.05$ & 0.016 & $\begin{array}{c}\text { Kecocokan } \\
\text { baik }\end{array}$ \\
\hline GFI & $\begin{array}{c}\text { Goodness Of Fit } \\
\text { Index }\end{array}$ & $\geq 0.90$ & 0.99 & $\begin{array}{c}\text { Kecocokan } \\
\text { baik }\end{array}$ \\
\hline AGFI & $\begin{array}{c}\text { Adjusted } \\
\text { Goodness Of Fit } \\
\text { Index }\end{array}$ & $\geq 0.90$ & 0.97 & $\begin{array}{c}\text { Kecocokan } \\
\text { baik }\end{array}$ \\
\hline Sumber : Hasil Penelitian (2018) & & & \\
\hline
\end{tabular}

Tabel 11.

Validitas dan Reliabilitas Variabel Laten pada Uji CFA

\begin{tabular}{|c|c|c|c|c|c|}
\hline $\begin{array}{l}\text { Variabel Laten / } \\
\text { Variabel } \\
\text { Teramati }\end{array}$ & $\begin{array}{l}\text { Nilai } \\
\text { SLF*) } \\
0.50\end{array}$ & $\begin{array}{c}\text { Nila } \\
\text { i } \\
\text { Err } \\
\text { or }\end{array}$ & $\begin{array}{c}\text { Nilai } \\
\left(R^{* *}\right) \\
0.70\end{array}$ & $\begin{array}{c}\text { Nilai } \\
\left.\mathrm{VE}^{i \pi *}\right) \geq \\
0.50\end{array}$ & $\begin{array}{l}\text { Kesimpulan } \\
\text { Perhitungan }\end{array}$ \\
\hline$K P$ & & & 0.98 & 0.81 & $\begin{array}{c}\text { Reliabilitas } \\
\text { baik }\end{array}$ \\
\hline KPL & 0.90 & 0.19 & & & Validitas baik \\
\hline$S U B$ & & & 0.98 & 0.81 & $\begin{array}{c}\text { Reliabilitas } \\
\text { baik }\end{array}$ \\
\hline SUBL & 0.90 & 0.19 & & & Validitas baik \\
\hline$H J$ & & & 0.98 & 0.81 & $\begin{array}{c}\text { Reliabilitas } \\
\text { baik }\end{array}$ \\
\hline HJL & 0.90 & 0.19 & & & Validitas baik \\
\hline$K M$ & & & 0.94 & 0.88 & $\begin{array}{c}\text { Reliabilitas } \\
\text { baik }\end{array}$ \\
\hline KML & 0.94 & 0.11 & & & Validitas baik \\
\hline$K K$ & & & 0.91 & 0.83 & $\begin{array}{c}\text { Reliabilitas } \\
\text { baik }\end{array}$ \\
\hline KKI & 0.91 & 0.17 & & & Validitas baik \\
\hline
\end{tabular}

*)SLF = Standardized Loading Factor; dimana nilai SLF yang baik $\geq 0.50$

$\left.{ }^{* *}\right) \mathrm{CR}=$ Construct Reliability; dimana nilai $C R$ yang baik $\geq 0.70$

$\left.{ }^{* * *}\right) \mathrm{VE}=$ Variance Extracted; dimana nilai $V E$ yang baik $\geq 0.50$

\section{Hasil Uji Model Struktural Penelitan dan Resume Uji Signifikansi}

Tahap akhir dari pengolahan dengan SEM adalah uji model structural yang menguji model penelitian dimana hasilnya berupa rincian hipotesa mana saja yang diterima dan ditolak. Hipotesa diterima jika nilai t $(\mathrm{T}-$ Value $)>1.96$ dan tanda koefisien (positif atau negatif) harus sesuai dengan pernyataan hipotesa.

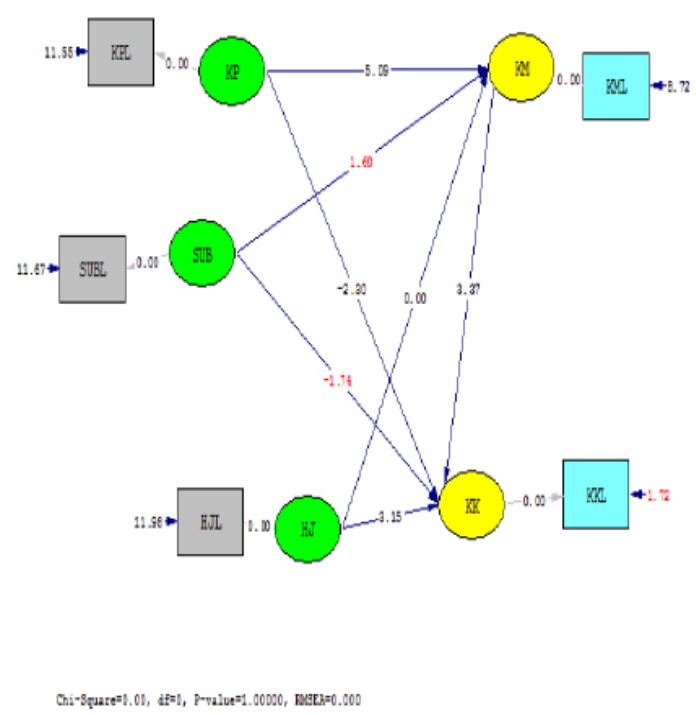

Gambar 8.

Hasil Uji Model Struktural Penelitian MODEL (T-Value)

Tabel 12.

GOFI Variabel Laten Uji Model Struktural Penelitian / Uji Hipotesa

\begin{tabular}{|c|c|c|c|c|}
\hline $\begin{array}{l}\text { Indikator } \\
\text { GOFI }\end{array}$ & $\begin{array}{c}\text { Keterangan } \\
\text { Indikator GOFI }\end{array}$ & $\begin{array}{c}\text { Nilai Standar } \\
\text { untuk } \\
\text { Kecocokan Baik }\end{array}$ & $\begin{array}{l}\text { Hasil } \\
\text { Hitung }\end{array}$ & Kesimpulan \\
\hline RMSEA & $\begin{array}{c}\text { Root Mean } \\
\text { Square Error of } \\
\text { Approximation }\end{array}$ & $\leq 0.08$ & 0.00 & $\begin{array}{c}\text { Kecocokan } \\
\text { baik }\end{array}$ \\
\hline NFI & $\begin{array}{l}\text { Normed Fit } \\
\text { Index }\end{array}$ & $\geq 0.90$ & 1.00 & $\begin{array}{l}\text { Kecocokan } \\
\text { baik }\end{array}$ \\
\hline NNFI & $\begin{array}{l}\text { Non-Normed Fit } \\
\text { Index }\end{array}$ & $\geq 0.90$ & 1.00 & $\begin{array}{c}\text { Kecocokan } \\
\text { baik }\end{array}$ \\
\hline CFI & $\begin{array}{l}\text { Comparative Fit } \\
\text { Index }\end{array}$ & $\geq 0.90$ & 1.00 & $\begin{array}{c}\text { Kecocokan } \\
\text { baik }\end{array}$ \\
\hline IFI & $\begin{array}{l}\text { Incremental Fit } \\
\text { Index }\end{array}$ & $\geq 0.90$ & 1.00 & $\begin{array}{l}\text { Kecocokan } \\
\text { baik }\end{array}$ \\
\hline RFI & $\begin{array}{l}\text { Relative Fit } \\
\text { Index }\end{array}$ & $\geq 0.90$ & 0.98 & $\begin{array}{c}\text { Kecocokan } \\
\text { baik }\end{array}$ \\
\hline Std. RMR & $\begin{array}{c}\text { Standardized } \\
\text { Root Mean } \\
\text { Square Residuan }\end{array}$ & $\leq 0.05$ & 0.016 & $\begin{array}{c}\text { Kecocokan } \\
\text { baik }\end{array}$ \\
\hline GFI & $\begin{array}{l}\text { Goodness Of Fit } \\
\text { Index }\end{array}$ & $\geq 0.90$ & 0.98 & $\begin{array}{c}\text { Kecocokan } \\
\text { baik }\end{array}$ \\
\hline AGFI & $\begin{array}{c}\text { Adjusted } \\
\text { Goodness Of Fit } \\
\text { Index }\end{array}$ & $\geq 0.90$ & 0.97 & $\begin{array}{c}\text { Kecocokan } \\
\text { baik }\end{array}$ \\
\hline
\end{tabular}

Sumber : Hasil Penelitian (2018) 
Tabel 13.

Hasil Uji Signifikansi Hipotesa Penelitian Berdasarkan Uji Model Struktural Penelitian

\begin{tabular}{|c|c|c|}
\hline $\begin{array}{c}\text { Hubungan/Pengaruh Antar } \\
\text { Variabel Laten }\end{array}$ & $\begin{array}{l}\text { Nilai } \\
\text { t hitung }\end{array}$ & $\begin{array}{l}\text { Kesimpulan Hasi Uji } \\
\text { Signifikansi Hipotesa }\end{array}$ \\
\hline $\begin{array}{l}\mathrm{Hl} \text { : Ada } \\
\text { hubungan/pengaruh antara } \\
\text { variabel laten } K P \text { (Kualitas } \\
\text { Produk) terhadap } K M \\
\text { (Keputusan Membeli). }\end{array}$ & 5.09 & $\begin{array}{l}\text { Hl diterima, nilai } \mathrm{t} \geq 1.96 \text {, } \\
\text { terdapat hubungan } \\
\text { /pengaruh positif antara } \\
\text { variabel } K P \text { terhadap } \\
\text { variabel } K M \text {. }\end{array}$ \\
\hline $\begin{array}{l}\text { H2: Ada hubungan/pengaruh } \\
\text { antara variabel laten SUB } \\
\text { (Subsidi/Insentif Pemerintah) } \\
\text { terhadap KM (Keputusan } \\
\text { Membeli). }\end{array}$ & 1.60 & $\begin{array}{l}\mathrm{H} 2 \text { ditolak, nilai } \mathrm{t}<1.96 \text {, } \\
\text { tidak terdapat hubungan } \\
\text { pengaruh antara variabel } \\
\text { SUB terhadap variabel } K M \text {. }\end{array}$ \\
\hline $\begin{array}{l}\text { H3: Ada hubungan/pengaruh } \\
\text { antara variabel laten } H J \\
\text { (Harga Jual) terhadap KM } \\
\text { (Keputusan Membeli). }\end{array}$ & 0.00 & $\begin{array}{l}\text { H3 ditolak, nilai } \mathrm{t}<1.96 \text {, } \\
\text { tidak terdapat hubungan } / \\
\text { pengaruh antara variabel } H J \\
\text { terhadap variabel } K M \text {. }\end{array}$ \\
\hline $\begin{array}{l}\text { H4: Ada } \\
\text { hubungan/pengaruh antara } \\
\text { variabel laten } K M \\
\text { (Keputusan Membeli) } \\
\text { terhadap KK (Kepuasan } \\
\text { Konsumen). }\end{array}$ & 3.37 & $\begin{array}{l}\mathrm{H} 4 \text { diterima, nilai } \mathrm{t} \geq 1.96, \\
\text { terdapat hubungan } \\
\text { /pengaruh positif antara } \\
\text { variabel } K M \text { terhadap } \\
\text { variabel } K K \text {. }\end{array}$ \\
\hline $\begin{array}{l}\text { H5: Ada hubungan/pengaruh } \\
\text { antara variabel laten } K P \\
\text { (Kualitas Produk) terhadap } K K \\
\text { (Kepuasan Konsumen). }\end{array}$ & -2.30 & $\begin{array}{l}\text { H5 ditolak, meski nilai } \mathrm{t} \leq \\
1.96 \text {, namun terdapat } \\
\text { hubungan / pengaruh negatif } \\
\text { antara variabel } K P \text { terhadap } \\
\text { variabel } K K \text {. }\end{array}$ \\
\hline $\begin{array}{l}\text { H6: Ada hubungan/pengaruh } \\
\text { antara variabel laten SUB } \\
\text { (Subsidi/Insentif Pemerintah) } \\
\text { terhadap KK (Kepuasan }\end{array}$ & -1.74 & $\begin{array}{l}\text { H6 ditolak, nilai } \mathrm{t}<1.96 \text {, } \\
\text { tidak terdapat hubungan } \\
\text { pengaruh antara variabel }\end{array}$ \\
\hline Konsumen). & & $S U B$ terhadap variabel $K K$. \\
\hline $\begin{array}{l}\text { H7: Ada } \\
\text { hubungan/pengaruh antara } \\
\text { variabel laten } H J \text { (Harga } \\
\text { Jual) terhadap KK (Kepuasan } \\
\text { Konsumen). }\end{array}$ & 3.15 & $\begin{array}{l}\mathrm{H} 7 \text { diterima, nilai } \mathrm{t} \geq 1.96 \text {, } \\
\text { terdapat hubungan } \\
\text { /pengaruh positif antara } \\
\text { variabel } H J \text { terhadap } \\
\text { variabel } K K \text {. }\end{array}$ \\
\hline
\end{tabular}

Terdapat pengaruh yang signifikan Kualitas Produk terhadap Keputusan Membeli. Kualitas Produk dalam hal ini kualitas rumah yang dibangun oleh pihak pengembang dapat diterima oleh masyarakat konsumen, kualitas rumah ini menyangkut design, bentuk, spesifikasi bangunan yang di berikan kepada konsumen sudah sesuai dengan yang diinginkan konsumen sehingga terdapat pengaruh yang signifikan Kualitas Produk terhadap Keputusan Membeli.
Tidak terdapat pengaruh yang signifikan Subsidi/Insentif Pemerintah terhadap Keputusan Membeli Ketika Masyarakat Konsumen melihat bahwa Subsidi/Insentif Pemerintah diberikan kepada semua perumahan dimanapun maka Konsumen tidak lagi memperhatikan faktor Subsidi/Insentif Pemerintah yang telah diberikan sebagai faktor penting yang menjadi pertimbangan dan memberikan pengaruh karena semua perumahan mendapatkan hal yang sama, menjadi penyebab tidak terdapat pengaruh yang signifikan Subsidi/Insentif Pemerintah terhadap Keputusan membeli. Konsumen sudah menganggap fasilitas Subsidi/Insentif dari pemerintah merupakan hal yang sudah umum terdapat dalam pemasaran Rumah Sederhana.

Ketika Pemerintah memberlakukan kebijakan satu harga kepada semua perumahan dimanapun maka Masyarakat Konsumen tidak lagi melihat bahwa Harga jual sebagai faktor penting yang menjadi pertimbangan dan mempengaruhi mereka dalam memutuskan pembelian. Menjadi penyebab tidak terdapat pengaruh yang signifikan Harga Jual terhadap Keputusan Membeli maka disarankan kepada pihak pengembang untuk tidak perlu memperhatikan faktor harga jual sebagai kendala didalam pemasaran Rumah Sederhana.

Terdapat pengaruh yang signifikan Keputusan Membeli terhadap Kepuasan Konsumen. Kualitas Produk dalam hal ini rumah sederhana yang ditawarkan, kemudian informasi dan pelayanan yang diberikan serta produk sejenis atau rumah yang sama yang ditawarkan oleh perumahan lain sebagai produk pesaing, telah memberikan pengaruh yang signifikan terhadap Kepuasan Konsumen,

Masyarakat / konsumen merasa apa yang dijanjikan pihak pengembang berbeda dengan realita atau kenyataan setelah mereka menerima rumah yang mereka pesan atau yang telah mereka beli, komitmen diawal pembelian tidak sesuai dengan apa yang mereka terima, 
sehingga menjadi penyebab tidak terdapat pengaruh Kualitas Produk terhadap Kepuasan Konsumen. Pemerintah melalui pengembang disarankan dalam membangun Rumah Sederhana, hendaknya memperhatikan faktor yang mempengaruhi Kepuasan Konsumen seperti Kualitas rumah, Pelayanan dan fasilitas umum yang mendukung perumahan tersebut sebagai bagian dari produk perumahan.

Ketika Masyarakat Konsumen melihat bahwa Subsidi/Insentif Pemerintah diberikan kepada semua perumahan dimanapun maka Konsumen tidak lagi memperhatikan faktor Subsidi/Insentif Pemerintah yang telah diberikan sebagai faktor penting yang menjadi pertimbangan dan memberikan pengaruh terhadap Kepuasan mereka sebagai Konsumen karena semua perumahan mendapatkan hal yang sama, menjadi penyebab tidak terdapat pengaruh yang signifikan Subsidi/Insentif Pemerintah terhadap Kepuasan konsumen dilihat dari distribusi jawaban responden atas pernyataan/Pertanyaan dalam kuesioner penelitian. Sehingga perhatian konsumen lebih kepada Harga jual terbukti pada Pengaruh Harga Jual terhadap Kepuasan yang terdapat pengaruh yang signifikan.

Terdapat pengaruh yang signifikan Harga Jual terhadap Kepuasan Konsumen. Hal ini berdasarkan hasil olah data dengan LISRELSEM. Harga Jual yang mendapatkan bantuan dalam bentuk Subsidi dari pemerintah membuat perhatian Masyarakat Konsumen begitu besar dan menarik minat mereka, apalagi harga jual rumah sederhana ditentukan oleh pemerintah serendah mungkin dengan mengacu pada upah minimum rata rata disuatu daerah. sehingga berpengaruh signifikan terhadap Kepuasan Konsumen/ Masyarakat.

\section{KESIMPULAN}

1. Berdasarkan hasil olah data dengan LISRELSEM yang menunjukkan nilai $T$ Statistics adalah 5.09 lebih besar dari 1.96. Dapat disimpulkan bahwa terdapat pengaruh yang signifikan Kualitas Produk terhadap Keputusan Membeli;
2. Berdasarkan hasil olah data dengan LISRELSEM yang menunjukkan nilai $\mathrm{T}$ Statistics adalah 1.6o kurang dari 1.96. Berarti tidak terdapat pengaruh yang signifikan Subsidi Insentif Pemerintah terhadap Keputusan Membeli;

3. Berdasarkan hasil olah data dengan LISRELSEM yang menunjukkan nilai $T$ Statistics adalah o,oo kurang dari 1.96. Berarti tidak terdapat pengaruh yang signifikan harga jual terhadap Keputusan Membeli;

4. Berdasarkan hasil olah data dengan LISRELSEM yang menunjukkan nilai $T$ Statistics adalah 3.37 lebih besar dari 1.96. Dapat disimpulkan bahwa terdapat pengaruh yang signifikan Keputusan Membeli terhadap Kepuasan Konsumen;

5. Berdasarkan hasil olah data dengan LISRELSEM yang menunjukkan nilai $T$ Statistics adalah -2,30 lebih kecil dari 1.96. Dapat disimpulkan bahwa tidak terdapat pengaruh yang signifikan Kualitas Produk terhadap Kepuasan Konsumen;

6. Berdasarkan hasil olah data dengan LISRELSEM yang menunjukkan nilai $T$ Statistics adalah -1,74 lebih kecil dari 1.96. Dapat disimpulkan bahwa tidak terdapat pengaruh yang signifikan Subsidi Insentif Pemerintah terhadap Kepuasan Konsumen;

7. Berdasarkan hasil olah data dengan LISRELSEM yang menunjukkan nilai $T$ Statistics adalah 3,15 lebih besar dari 1.96. Dapat disimpulkan bahwa tidak terdapat pengaruh yang signifikan Harga Jual terhadap Kepuasan Konsumen;

\section{SARAN}

1. Perhatian dan pengawasan dari pihak Pemerintah sangat dibutuhkan dalam penyediaan rumah sederhana ini karena pembangunan dan proses pemasarannya dilakukan oleh pihak swasta agar kualitas produk dan pelayanan bagi masyarakat yang menerima sesuai dengat standar kualitas dan layanan yang seharusnya mereka terima;

2. Pengawasan dan masukan dari masyarakat juga penting untuk disampaikan kepada pemerintah agar penyaluran Rumah Sederhana dan subsisdi yang diberikan oleh 
Pemerintah untuk masyarakat benar benar efektif Karena Perhatian masyarakat lebih terpusat kepada Harga Jual dan Kualitas Rumah yang berpengaruh kepada Kepuasan Konsumen.

3. Bagi pihak swasta terutama perusahaan pengembang atau developer yangdiberi kepercayaan untuk membangun dan memasarkan Rumah sederhana oleh Pemerintah haruslah memperhatikan hak hak konsumen.

4. Perlu adanya penelitian lanjutan karena penulis menyadari betul bahwa penelitian ini masih membutuhkan kajian yang lebih mendalam dengan dukungan teori yang lebih kuat, karena di dalam penelitian ini hanya mengangkat sebagian kecil saja dari phenomena persoalan yang begitu banyak dalam proses penyediaan dan pemasaran rumah sederhana bagi masyarakat berpenghasilan rendah.

\section{DAFTAR PUSTAKA}

Engel, J. F., Blackwell, R. D. and P.W. Miniard, (1990). Consumer Behavio. 6th ed. Dryden Press, Chicago: Dryden Press. analisis kepuasan penghuni perumahan sederhana di denpasar berdasarkan faktor lokasi, prasarana, sarana, kualitas bangunan, desain dan harga (Program Pasca Sarjana Institut Teknologi Sepuluh Nopember Surabaya).

Fillmore. Galaty, (1991). Modern Real Estate. Chicago: Real Estate Education Company.

Hanan, M. and P. Karp, 1989. Customer Satisfaction: How to Maximize, Measure, and Market Your Company's "Ultimate Product".New York..

Kurniawan,Heri, (2010). “ Partial Least Square (PLS) sebagai Metode Alternatif SEM Berbasis Variant (Lisrel) dalam Explorasi Data Summary dan data Maining.
Kotler,Philip dan Amastrong,Garry 2001, Dasar dasar Pemasarn Jakarta: PT Indeks.

Limanto, S.. (2009). Model Analisis Investasi Pengembang Perumahan. Simposium Nasional RAPI VIII 2009, ISSN : 14129612.

Mowen, J. C. (1995). Consumer Behavior 4 th ed. New York: Prentice-Hall International, Inc.,. Dalam Jurnal analisis kepuasan penghuni perumahan sederhana di denpasar berdasarkan faktor lokasi, prasarana, sarana, kualitas bangunan, desain dan harga.

Silas, John, (1997). Evaluasi Pembangunan Perumahan - Tinjauan Kritis Terhadap Keterlibatan Rakyat, Seminar Nasional Kemitraan Dalam Pembangunan Perumahan, Yogyakarta.

Soehardi dan Sherlito C. Sable, (2019). Strategi Pemasaran Bisnis Pariwisata di Kota Davao, Filipina. Jakarta: Jurnal Ilmiah Manajemen Ubhara atau http://jurnal.ubharajaya.ac.id/index.ph $\mathrm{p} /$ manajemen-ubhara

Sudaryono, (1997). Konsep Kemitraan Dalam Pembangunan Perumahan; seminar Nasional Kemitraan Dalam Pembangunan Perumahan, Yogyakarta,

Sugiyono. 2001. Metode Penelitian Bisnis Bandung: Alfabeta.

Swasta dan Handoko, 1987, Manajemen Pemasaran Analisa Perilaku Konsumen, Liberti, Yogyakarta.

Tjiptono, Fandy, 2008. Setrategy Pemasaran Yogyakarta CV Andy Ofset.

Turner, John, 1982. F. Housing by People. London. Marion Boyars Publishers Ltd. 